세프트리악손 투여 후 발생한 급성 췌장염

강원대학교 의학전문대학원 강원대학교병원 내과

이진미 · 박진명 · 김지현 · 이원구 · 이상훈 · 남승주 · 강창돈 · 이성준

\title{
Ceftriaxone-induced Acute Pancreatitis in an Adult
}

\section{Jin Mi Lee, Jin Myung Park, Ji Hyun Kim, Won Gu Lee, Sang Hoon Lee, Seung- Joo Nam, Chang Don Kang,} Sung Joon Lee

Department of Internal Medicine, Kangwon National University Hospital, Kangwon National University School of Medicine, Chuncheon, Korea

Ceftriaxone is commonly used for the treatment of bacterial infection. But it may precipitate in bile causing biliary sludge, pseudolithiasis and gallstone especially in children. We report a case of ceftriaxone-induced acute pancreatitis in an old woman. An 83-year-old woman was admitted for treatment of renal stone. She had received intravenous ceftriaxone for 11 days. After percutaneous nephrolithotomy, she was discharged. After 12 days, she visited the emergency department due to epigastric pain. Laboratory finding was suggestive of gallstone pancreatitis and abdominal computed tomography revealed gallbladder stone, which was absent previously. After conservative care, she received cholecystectomy and discharged without sequelae.

Korean J Pancreas Biliary Tract 2019;24(3):116-120

Keywords: Ceftriaxone, Pancreatitis, Gallstones

\author{
Received Jun. 3, 2019 \\ Revised Jun. 20, 2019 \\ Accepted Jun. 21, 2019
}

Corresponding author : Jin Myung Park

Department of Internal Medicine, Kangwon National University Hospital, Kangwon National University School of Medicine, 156 Baengnyeong-ro, Chuncheon 24289, Korea

Tel. +82-33-258-9235 Fax. +82-33-258-2404

E-mail; youreon.park@gmail.com

ORCID: https://orcid.org/0000-0002-8798-0587
This is an Open Access article distributed under the terms of the Creative Commons Attribution Non-Commercial License (http:/ creativecommons.org/licenses/by-nc/3.0/) which permits unrestricted non-commercial use, distribution, and reproduction in any medium, provided the original work is properly cited.

Copyright $\odot 2019$ by The Korean Journal of Pancreas and Biliary Tract

\section{서 론}

세프트리악손(ceftriaxone)은 항균 범위가 넓고 반감기가 길어 임상에서 널리 사용되고 있는 3 세대 세팔로스포린계의 항생제이다. 하지만 고용량으로 장기간 사용 시 드물게 담낭 및 담도에 침전물이나 결석을 생성하는 부작용이 발생할 수 있다. ${ }^{1}$ 세프트리악손 관련 가성담석(ceftriaxone-associated pseudolithiasis)은 주로 소아에서 보고되었고, 대부분 증상을 유발하지 않지만 드물게 담낭염, 췌장염 또는 총담관폐색과 같은 심각한 합병증이 동반되는 경우도 보고가 된 바 있다. ${ }^{2}$
저자들은 요로결석을 치료하는 과정에서 세프트리악손을 투여한 후 급성 췌장염이 발생한 증례를 경험하여 문헌고찰과 함께 보고하는 바이다.

\section{증 례}

83세 여자가 3 일 전 시작된 명치 통증을 주소로 응급실에 내원하였다. 체한 듯하고 답답한 느낌이 지속되었으며 증상은 식사 후 악화되는 양상이었다. 구역감, 구토가 동반되었고 발열은 없었다. 기저질환으로 고혈압 및 당뇨가 있었고, 내원 
3 주 전 신장결석으로 비뇨의학과에 입원하여 경피적 신쇄석술 후 퇴원한 이력이 있었다. 당시 세프트리악손 $2 \mathrm{~g}$ 을 하루 1 회씩 총 11 일간 주사로 투여받았다. 췌장염의 과거력은 없었고 음주 및 흡연도 부인하였다.

내원 당시 혈압 $170 / 90 \mathrm{mmHg}$, 맥박 95 회/분, 호흡수 24 회/분, 체온은 $36.9^{\circ} \mathrm{C}$ 였다. 진찰 시 복부는 편평하였으며 장음은 정상이었고 명치 부위에 압통이 있었다. 반발통은 동반되지 않았다.

혈액검사에서 white blood cell $10.3 \times 10^{3} / \mathrm{uL}$ (참고치 3.8-10.0 $\left.\times 10^{3}\right)$, hemoglobin $12.7 \mathrm{~g} / \mathrm{dL}(12.6-15.0)$, platelet $228 \times 10^{3} / \mathrm{uL}$ $\left(140-400 \times 10^{3}\right)$ 로 백혈구 증가증을 보였다. 그리고 blood urea nitrogen $27.5 \mathrm{mg} / \mathrm{dL}$ (9.0-23.0), creatinine $1.2 \mathrm{mg} / \mathrm{dL}$ (0.5-1.1),

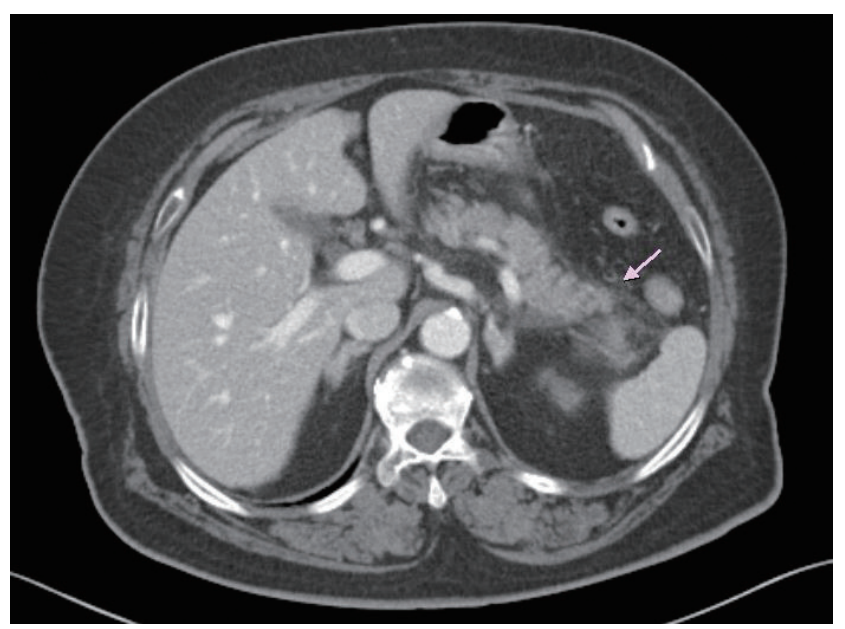

Fig. 1. Computed tomography revealed peripancreatic fatty infiltration and small amount of fluid collection (arrow) in peripancreatic space. total bilirubin $1.4 \mathrm{mg} / \mathrm{dL}(0.3-1.2)$, aspartate transaminase/alanine transaminase 294/292 IU/L (0-34/10-49), alkaline phosphatase 229 IU/L (45-129), amylase/lipase 4,025/>3,500 IU/L (30-118/1253 )로 이상 소견을 보였다. 이 외에 $\mathrm{Na} / \mathrm{K} 139 / 4.5 \mathrm{mEq} / \mathrm{L}$ (132-146/3.5-5.5), chloride $106 \mathrm{mEq} / \mathrm{L}$ (99-109), total calcium $9.5 \mathrm{mg} / \mathrm{dL}$ (8.7-70.4), triglyceride $87 \mathrm{mg} / \mathrm{dL}$ (0-200), immunoglobulin G 646.4 mg/dL (700-1,600), immunoglobulin G4 55 mg/dL (39.2864.0), C-reactive protein $0.3 \mathrm{mg} / \mathrm{dL}$ (<0.5)로 나타났다.

복부 전산화단층촬영(computed tomography, CT) 결과 췌장 주위에 침윤 소견이 보였고(Fig. 1), 담낭에 다발성 담석이 관찰되었으며, 총담관담석은 보이지 않았다(Fig. 2A). 담낭 담석은 3주 전 비뇨의학과 입원 당시 촬영한 CT에서는 보이지 않았던 소견이었다(Fig. $2 \mathrm{~B}$ ). 내시경 초음파 검사에서도 담낭에 담석이 보였으며 총담관담석은 관찰되지 않았다(Fig. 3).

이에 세프트리악손 투여 후 발생한 담석에 의하여 유발된 급성 췌장염으로 진단하였고, 금식, 수액공급, 진통제 처방 등 보존적 치료 후 복통은 호전되었다. 입원 11 일째에 복강경 담낭절제술을 시행하였고 수술 후 별다른 문제없이 퇴원 하였다. 5 개월 후 외래 추적관찰하였고 복통이나 황달 등의 문제는 발생하지 않았다.

\section{고 찰}

가성담석은 세프트리악손을 투여한 환자의 담낭이나 담도에서 관찰되는 영상학적 이상 소견을 가리키는 용어로 1988년 Schaad 등 ${ }^{1}$ 에 의하여 처음 사용되었다. 이들의 연구에는
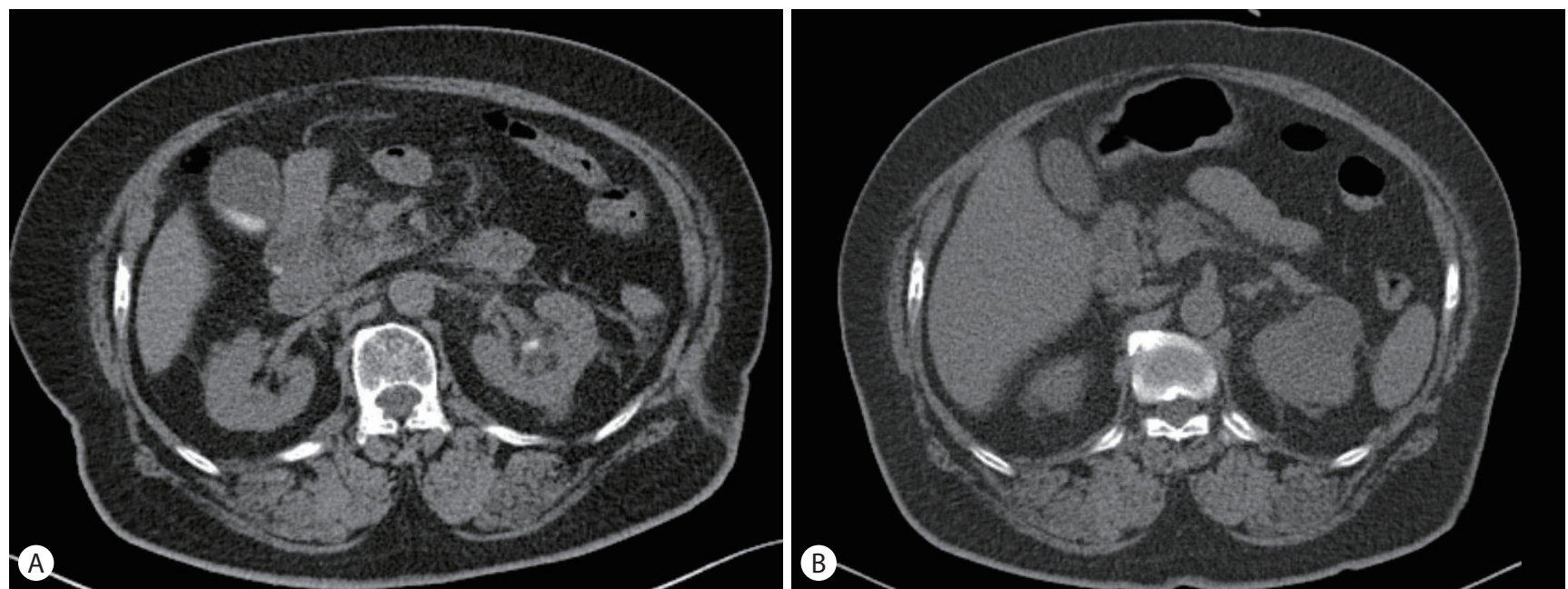

Fig. 2. (A) Non-enhance computed tomography (CT) revealed gallbladder stone, (B) which was not seen in previous CT 3 weeks ago. 

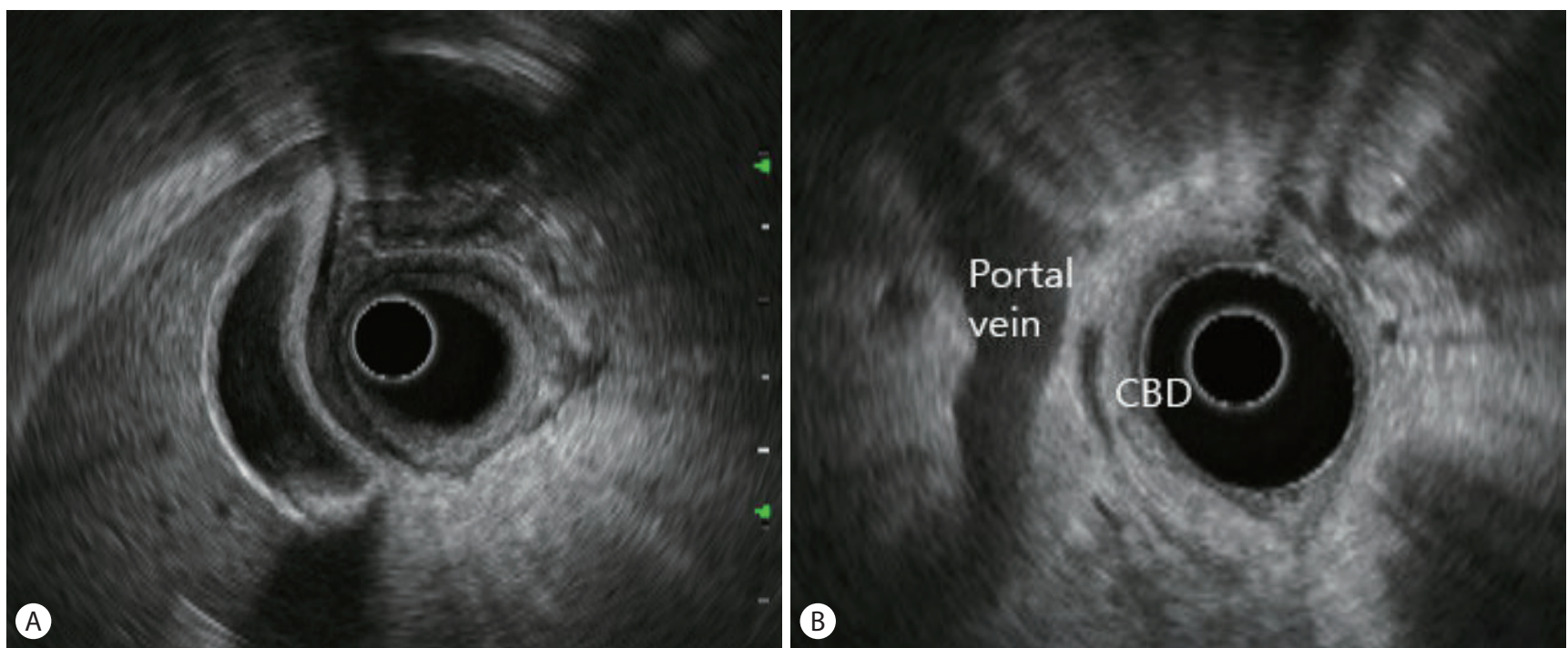

Fig. 3. (A) Endoscopic ultrasonography revealed gallbladder stone. (B) CBD dilation or stone was not seen. CBD, common bile duct.

Table 1. Reported cases of ceftriaxone-induced acute pancreatitis

\begin{tabular}{|c|c|c|c|c|}
\hline Study & Sex/age & Daily dose & Duration & Subsequent management \\
\hline Zimmermann et al. (1993) & $\mathrm{F} / 71$ & $2 \mathrm{~g}$ & 3 days & Conservative \\
\hline Maranan et al. (1998) ${ }^{9}$ & $M / 18$ & $4 \mathrm{~g}$ & 5 weeks & Cholecystectomy \\
\hline Famularo et al. (1999) & $\mathrm{F} / 71$ & $2 \mathrm{~g}$ & 10 days & Cholecystectomy \\
\hline Sasaki et al. (2009) & $F / 35$ & $2 \mathrm{~g}$ & 9 days & Conservative \\
\hline Ruggiero et al. $(2010)^{12}$ & $\mathrm{M} / 2$ & $0.7 \mathrm{~g}$ & 2 days & Conservative \\
\hline Nakagawa et al. $(2017)^{13}$ & $\mathrm{M} / 74$ & $2 \mathrm{~g}$ & 5 days & ERCP \\
\hline Kang and Song $(2018)^{14}$ & $\mathrm{M} / 70$ & $2 \mathrm{~g}$ & 25 days & Conservative \\
\hline Present case (2019) & $\mathrm{F} / 83$ & $2 \mathrm{~g}$ & 11 days & Cholecystectomy \\
\hline
\end{tabular}

F, female; M, male; ERCP, endoscopic retrograde cholangiopancreatography.

다양한 감염증으로 세프트리악손을 투여받은 37명의 소아가 포함되었는데, 이 중 16 명에서 복부 초음파 검사시 담도 침전물이 확인되었고, 3 명에서 이로 인한 증상이 동반되었다. 이들은 평균 7일(범위 4-33일)에 걸쳐 $89 \mathrm{mg} / \mathrm{kg} / \mathrm{day}(54-105 \mathrm{mg} / \mathrm{kg} / \mathrm{day})$ 의 세프트리악손을 투여받았고 증상 및 초음파 이상 소견은 세프트리악손 투여 중단 후 사라진 것으로 나타났다.

세프트리악손은 정맥으로 투여 시 85-95\%가 혈중 단백질, 대개는 알부민과 결합하여 오랫동안 혈액에 남아 있게 되고, 대략 40-60\%가 소변으로, 나머지는 담즙으로 배설된다. ${ }^{3}$ 음이온의 성질을 가지고 있어 칼슘에 친화력이 높고 담낭 내 축적 시 불용성 칼슘염을 만들어 침전물 및 가성담석을 형성할 수 있다. ${ }^{4}$ 가성담석은 $20-250 \mu \mathrm{m}$ 의 미세 침전물로 대부분은 세프트리악손-칼슘염으로 구성되어 있고 소량의 콜레스테롤과 bilirubin이 포함되어 있다. 5
성인에서의 세프트리악손 연관 가성담석 증례들이 전 세계적으로 보고되고 있으며, 발생시점은 투약 후 2-30일로 나타났다. 또한 항생제 투여 중단 후 담석이 사라지는 데 걸리는 시간은 2일-12개월로 다양하게 보고되었다. ${ }^{2}$ 세프트리악손 연관 담석 발생의 위험인자로는 고용량(>2 g/day) 및 장기간의 투여, 금식 또는 완전비경구영양을 하는 경우, 침상안정, 신기능저하 등이 알려져 있다. ${ }^{5-7}$ 활동량이 적고 탈수의 위험이 높은 고령의 환자에서 발생률이 높을 것을 예상할 수 있으므로, 세프트리악손을 투여하는 고위험군 환자의 경우 담낭염, 췌장염과 같은 합병증이 발생하는지 주의 깊은 관찰이 필요하다. 가성담석의 발생을 예방하기 위해서는 세프트리악손 투여 기간을 줄이고 충분한 수액 공급을 유지하며, 과도한 침상안정을 피하는 것이 좋다. ${ }^{2}$

본 증례는 음주력이 없었고 담석 췌장염에 합당한 혈액검사 
소견을 보였으며, 세프트리악손 투여 전에는 보이지 않던 담석이 새로 관찰되었기 때문에 세프트리악손 연관 담석 및 이에 의한 췌장염으로 진단하였다. 환자의 신기능 저하, 요로결석 수술 및 이로 인한 침상 안정이 담석 생성의 위험인자로 작용하였을 것으로 생각된다.

세프트리악손 유발 췌장염에 대한 보고는 흔치 않다. PubMed 및 Korea Med에서 “ceftriaxone”과 “pancreatitis”가 제목에 포함된 문헌을 검색하였을 때 7건의 증례보고가 확인되었으며, 국내에서도 70 세 남성 간농양 환자에서 발생한 1예가 보고된 바 있다. ${ }^{8-14}$ 기존의 증례보고를 살펴보면, 남녀노소에서 모두 발생하였고, 투여 기간은 이틀부터 몇 주에 이르기까지 다양하였다. 성인 환자의 경우 모두 하루 $2 \mathrm{~g}$ 이상 투여하였고 보존적 치료만 시행한 경우부터 내시경역행담췌관조영술이나 담낭절제술까지 여러 치료가 시행되었음을 알 수 있다(Table 1). 아직까지 세프트리악손으로 인한 가성담석증 및 이에 의한 합병증이 발생하였을 때 치료에 대한 명확한 방침은 없으나 다음과 같은 세 가지 방법을 고려할 수 있을 것으로 생각된다.

첫째, 세프트리악손을 중단하고 ursodeoxycholic acid를 투여하는 방법이다. 실제로 세프트리악손 유발 가성담석에 대한 기존 연구에서는 대부분 투약 중단 후 가성 담석이 소실된 것으로 보고되었다. ${ }^{1,2}$ 하지만 본 증례는 세프트리악손 투약을 중단한 지 11 일이 지난 상태에서 췌장염이 발생하였기 때문에 가성담석이 완전히 소실되기 전 췌장염이 재발할 가능성을 배제할 수 없다. 아울러 ursodeoxycholic acid가 일반적인 담석이 아닌 세프트리악손 유발 가성담석에도 효과가 있을지는 불확실하다.

둘째, 내시경역행담췌관조영술 및 내시경적 유두절개술을 시행하는 방법이다. 기존의 연구 및 가이드라인 ${ }^{15}$ 에 따르면 담석성 췌장염에서 유두절개술만 시행한 경우 담낭절제술을 시행한 군에 비하여 췌장염 재발에 차이가 없었다. 하지만 이 경우에도 담도계 관련 증상의 재발이나 합병증의 발생은 담낭절제술을 시행한 군에 비하여 많은 것으로 보고되었다. 따라서 담낭절제술을 시행하지 못하는 경우가 아니라면 유두부 절개술만 시행하는 것은 추천하지 않고 있다. 다만 상기 가이드라인은 일반적인 담석에 의한 급성 췌장염을 대상으로 한 것이고, 세프트리악손에 의한 가성담석은 대부분의 환자에서 저절로 소실되기 때문에 가이드라인의 내용을 일률적으로 적용할 수 있을지는 불분명하다.

셋째, 담낭절제술을 시행하는 방법이 있다. 이 경우 담석 췌장염 환자의 증상 재발이나 합병증 발생을 줄일 수 있다는
장점이 있으나 수술을 시행해야 한다는 것이 부담이다. 본 증례에서는 세프트리악손 투약을 중단한 지 11 일이 지난 상태에서 췌장염이 발생하였고, 이전에 가성담석이 없어지는 데 최대 12 개월까지 걸렸다는 보고 ${ }^{2}$ 가 있어 가성담석이 소실되기 전 췌장염이나 다른 담도계 합병증이 추가로 발생하는 것을 예방하기 위하여 담낭절제술을 시행하였다. 기존의 세프트리악손 유발 가성담석에 의한 췌장염 증례를 살펴보면 투약 중단 후 경과 관찰, 내시경역행담췌관조영술, 담낭절제술 등 여러 치료가 시행되었고 대부분 장기 추적 결과가 언급되어 있지 않아 어떤 것이 가장 적절한 치료법인지 결론을 내리기 어렵다. 이에 대해서는 추후 더 많은 연구가 필요하다고 생각된다.

세프트리악손 투여 후에는 부작용으로 가성담석이 발생할 수 있지만 이로 인하여 급성 췌장염이 발생하는 경우는 드물다. 저자들은 80 대 여성에서 요로결석치료 중투여한세프트리악손에 의하여 담석이 생겼고, 이로 인하여 급성 췌장염이 발생한 1 예를 경험하였기에 문헌고찰과 함께 보고하는 바이다.

\section{요 약}

83세 여자 환자가 신장결석으로 입원하여 금식, 세프트리악손 투여 및 경피적 신쇄석술 후 퇴원하였고, 이후 명치 통증이 발생하여 응급실로 내원하였다. 혈액검사 및 복부 전산화 단층촬영에서 담석 및 췌장염 소견을 확인하였고, 담석은 이전에 보이지 않던 소견이었다. 이에 세프트리악손 유발 담석에 의한 급성 췌장염으로 진단하였고 보존적 치료 및 담낭절제술 후 퇴원한 예를 경험하여 보고하는 바이다.

국문 색인: 세프트리악손, 췌장염, 담석

\section{Conflicts of Interest}

The authors have no conflicts to disclose.

\section{REFERENCES}

1. Schaad UB, Wedgwood-Krucko J, Tschaeppeler H. Reversible ceftriaxone-associated biliary pseudolithiasis in children. Lancet 1988;2:14111413.

2. Abe S. A case of ceftriaxone-associated biliary pseudolithiasis in an elderly patient with renal dysfunction. IDCases 2017;9:62-64.

3. Richards DM, Heel RC, Brogden RN, Speight TM, Avery GS. Ceftriaxone. A review of its antibacterial activity, pharmacological properties and 
therapeutic use. Drugs 1984;27:469-527.

4. Park HZ, Lee SP, Schy AL. Ceftriaxone-associated gallbladder sludge. Identification of calcium-ceftriaxone salt as a major component of gallbladder precipitate. Gastroenterology 1991;100:1665-1670.

5. Shiffman ML, Keith FB, Moore EW. Pathogenesis of ceftriaxone-associated biliary sludge. In vitro studies of calcium-ceftriaxone binding and solubility. Gastroenterology 1990;99:1772-1778.

6. Murata S, Aomatsu T, Yoden A, Tamai H. Fasting and bed rest, even for a relatively short period, are risk factors for ceftriaxone-associated pseudolitiasis. Pediatr Int 2015;57:942-946.

7. Imafuku A, Sawa N, Sekine A, et al. Risk factors of ceftriaxone-associated biliary pseudolithiasis in adults: influence of renal dysfunction. Clin Exp Nephrol 2018;22:613-619.

8. Zimmermann AE, Katona BG, Jodhka JS, Williams RB. Ceftriaxoneinduced acute pancreatitis. Ann Pharmacother 1993;27:36-37.

9. Maranan MC, Gerber SI, Miller GG. Gallstone pancreatitis caused by ceftriaxone. Pediatr Infect Dis J 1998;17:662-663.

10. Famularo G, Polchi S, De Simone C. Acute cholecystitis and pancre- atitis in a patient with biliary sludge associated with the use of ceftriaxone: a rare but potentially severe complication. Ann Ital Med Int 1999;14:202-204.

11. Sasaki Y, Aoki S, Aoki K, et al. Acute pancreatitis associated with the administration of ceftriaxone in an adult patient. Nihon Shokakibyo Gakkai Zasshi 2009;106:569-575.

12. Ruggiero S, DI Nardo R, Polimeno T, Rossi F, Capuano A. Ceftriaxoneinduced pancreatitis in a pediatric patient: case report. J Chemother 2010;22:63-65.

13. Nakagawa N, Ochi N, Yamane $H$, et al. Ceftriaxone-associated pancreatitis captured on serial computed tomography scans. Radiol Case Rep 2017;13:43-46.

14. Kang SM, Song JE. Ceftriaxone-induced acute pancreatitis in patient with liver abscess. Korean J Pancreas Biliary Tract 2018;23:82-86.

15. Koh DH, Kim JH, Lee J, Choi HS. Clinical practice guidelines for acute pancreatitis: the diagnosis of acute pancreatitis. Korean J Pancreas Biliary Tract 2013;18:4-13. 